\title{
Glucocorticoid Hormones and Early Brain Development in Schizophrenia
}

\author{
James I. Koenig Ph.D., Brian Kirkpatrick M.D., and Paul Lee, A.B.
}

While genetic factors play a role in the etiology of schizophrenia, environmental factors contribute to the etiology of the disorder as well. If a woman is exposed during the second trimester of gestation to stressors such as the death of a loved one, influenza infection, or natural and man-made disasters, her baby has an increased risk of developing schizophrenia later in life. A common mechanism may mediate the effects of these diverse risk factors: a stress response during a restricted period of gestation may affect fetal brain development and, given the appropriate genetic predisposition, result in schizophrenia in adult life. Findings in animals exposed to prenatal stress strengthen the hypothesis that exposure to high glucocorticoid levels and/or other components of the stress response increases the risk of schizophrenia. These clinical and preclinical studies could be used to develop hypotheses that could then be tested in patients with schizophrenia.

[Neuropsychopharmacology 27:309-318, 2002] (C) 2002 American College of Neuropsychopharmacology. Published by Elsevier Science Inc.
KEY WORDS: Stress; Schizophrenia; Brain; Development; Glucocorticoid; Cortisol

Although genetic factors clearly play a role in the etiology of schizophrenia, there is also an extensive literature on non-genetic risk factors. Most of the reported environmental risk factors relate to pregnancy and labor, e.g., winter birth, obstetrical complications and prenatal malnutrition (Torrey et al. 1997; Brixey et al. 1993; Dalman et al. 1999; Susser et al. 1996). Although the mechanism by which these might lead to schizophrenia is unknown, the findings on these risk factors have been important contributions that reinforce the neurodevelopmental hypothesis of schizophrenia and

From the Maryland Psychiatric Research Center, Department of Psychiatry, University of Maryland School of Medicine, Baltimore, Maryland.

Address correspondence to: James I. Koenig, Ph.D., Maryland Psychiatric Research Center, P.O. Box 21247, Baltimore, MD 21228, Tel.: (410) 402-7319, fax: (410) 402-6066, E-mail: jkoenig@mprc. umaryland.edu

Received December 19, 2000; revised August 22, 2001; accepted October 22, 2001.

Online publication: 10/24/01 at www.acnp.org/citations/ Npp102401194. provide a basis for focusing on early brain development in a search for pathophysiological mechanisms in the disorder.

In combination, epidemiological and animal research suggest a mechanism by which prenatal stressors might increase the risk of schizophrenia in adult life. In this review, we will examine the common factor that can be identified in these disparate studies.

\section{EPIDEMIOLOGICAL STUDIES}

Huttunen and Niskanen (1978) tested the hypothesis that stress on the mother during gestation would impact on the baby's psychological development. They found that subjects whose fathers had died before their child's birth had an increased risk of psychiatric disorders, including psychosis, compared with subjects whose fathers died during the first year of their child's life. The risk was greatest if the father's death occurred during the third, fifth, ninth, or tenth four-week period of gestation. Mednick et al. (1988) subsequently reported that a mother's exposure to influenza during gestation was associated with an increased risk of 
schizophrenia in her child. Only the middle trimester of gestation was associated with an increased risk of the disorder, leading Mednick et al. to suggest that "it is less the type than the timing of the disturbance during fetal neural development that is critical in determining risk for schizophrenia." A potential weakness of this first study of influenza was the "ecological fallacy," as not everyone who is in an area of increased infection contracts the infection of interest. In order to address this potential confound, the same researchers examined gestational records. They found that women with documented influenza-like syndromes were, in fact, the ones whose children had an increased risk of schizophrenia (Mednick et al. 1994).

The putative role of influenza as a risk factor for schizophrenia is controversial (Crow 1994). Some studies have replicated the effect (Izumoto et al. 1999; Kunugi et al. 1995), whereas others have not (Morgan et al. 1997; Susser et al. 1994; Westergaard et al. 1999). A review found relative consistency in studies of the 1957 pandemic, but less consistency for other influenza epidemics (McGrath and Castle 1995). The effect size is small at best, accounting for a small percentage of all cases of schizophrenia.

However, since the initial reports on influenza other studies have suggested that, as Mednick, Huttenen, and coworkers (Mednick et al. 1988) hypothesized, exposure to other prenatal stressors during the second trimester may also increase the risk of schizophrenia. A reported association between the risk of schizophrenia and the incidence of respiratory infections other than influenza (O'Callaghan et al. 1994), and the replicated association between prenatal exposure to polio virus and risk of schizophrenia (Torrey et al. 1988; Suvisaari et al. 1999) both suggest the influenza effect cannot be attributed to something unique about that one particular virus. Brown et al. (2000) found that prenatal exposure to respiratory infections also increases the risk of both psychotic and nonpsychotic disorders within the schizophrenia spectrum. Again, the increased risk was restricted to mid-gestation.

A direct effect of the virus itself is the most obvious explanation for the association between prenatal infections and increased risk of schizophrenia, but evidence that the fetus is infected with the virus does not exist. A proposed mechanism for influenza's effect on the risk of schizophrenia is a change in brain development due to the maternal or fetal immune response (Wright et al. 1993; Smith 1992). Wright et al. (1993) suggested the maternal immune response to the infection yielded antibodies to fetal brain proteins. Crow (1987) proposed that some viral species insert genes into vulnerable individuals with existing genetic predispositions.

Other studies suggest that none of the factors specific to infection, such as fever or an immune response, is required for prenatal stress to affect the development of the fetus. Van Os and Selten (1998) found that subjects who were in mid-gestation during the 1940 invasion of Holland had an increased risk of schizophrenia in later life. Mothers exposed to the nuclear explosion in Nagasaki also were at increased risk for having schizophrenic offspring if they were in their second rather than third trimester of pregnancy at the time of the explosion (Imamura et al. 1999). Myhuman et al. (1996) examined self-ratings of a woman's desire to be pregnant. The ratings were gathered prospectively beginning in the 6th or 7th month of gestation. Children whose mothers did not want to be pregnant had an increased risk of schizophrenia. This association was present after accounting for both maternal depression and measures of fetal wellbeing at the time of birth. Mothers whose children developed schizophrenia also reported greater depression during gestation (Jones et al. 1998). A recent study also found an increased risk of schizophrenia if the subject's mother was exposed to a tornado during the second trimester of gestation (Kinney et al. 1999). However, another natural disaster, a flood associated with a severe storm, was reported not to increase the incidence of schizophrenia (Selten et al. 1999).

There are important limitations in these psychological stress studies, the most important being the lack of attempted replications. In some instances it will not be possible to attempt a close replication study. Moreover, there is a potential for confounding of the association between risk of schizophrenia and prenatal stress. Loss of a spouse, an unwanted pregnancy, and foreign invasion may all be associated with malnutrition and an increase in the incidence of infectious diseases, both of which are possible risk factors for schizophrenia (Susser et al. 1994, 1996; O'Callaghan et al. 1994). Furthermore, exposure to a nuclear blast obviously has physiological effects in addition to a stress response, and can affect the baby directly. It is also possible that genetic risk confounded the relationship between unwantedness of a pregnancy and risk of schizophrenia in the offspring. Women in the schizophrenia spectrum, who would confer an increased genetic risk of schizophrenia on their children, may wish not to have a baby more frequently than do other women.

\section{HYPOTHESIS}

Although the limitations of the above mentioned studies need to be kept in mind, these studies do raise the possibility of a single pathophysiological mechanism underlying the association of both viral infection and psychological stressors, and the risk of schizophrenia. The common denominator tying these diverse studies together is the stress response known to be precipitated by both viral infection and psychological stress. However, stress is a complex physiological response to environmental per- 
turbations, and while the glucocorticoids are the hallmark of the stress response, other factors may also be released that affect changes in the fetal brain, e.g. cytokines, such as interleukin-1 and interleukin-6.

Survivors of natural disasters have abnormal hypothalamic-pituitary-adrenal axis responses (Goenjian et al. 1996), and viral infection raises circulating cortisol levels (Trgovcich et al. 1997). Several of the cytokines involved in the immune response, including IL-1, IL-6, and TNF, also are known to increase the secretion of glucocorticoid hormones (for a review see Turnbull and Rivier, 1999). However, Parker and colleagues (Parker et al. 1993; Falkenberg et al. 1999) clearly demonstrated that maternal infections raise fetal levels of cortisol, providing evidence to support an involvement of adrenal steroid hormones in altering fetal brain development and thus, decreasing the likelihood that maternal cytokines influence the development of the fetal brain. Additionally, in situations where psychogenic stresses are employed, cytokine expression and glucocorticoid secretion can be dissociated from one another (PlataSalaman et al. 2000) although physical stresses may induce a release of cytokines as well as glucocorticoids (Takaki et al. 1994). Interestingly, Barbazanges et al. (1996) reported that maternal adrenalectomy prevented the effects of prenatal stress on the developing fetal brain and glucocorticoid replacement reinstates the effects of the prenatal stress. Gardner et al. (2001) also reported that fetal hypoxia increases fetal glucocorticoid levels. Therefore, many of the environmental risk factors associated with schizophrenia can be associated with fetal glucocorticoid exposure, potentially of maternal origin, further enforcing the importance of minimizing exposure of the fetal brain to glucocorticoids.

Indirect support for the hypothesis that elevated glucocorticoid levels, regardless of cause, leads to increased risk for schizophrenia also comes from the study of Schaefer et al. (2000), who found that obesity in the mother is a risk factor for schizophrenia in the offspring. Conversely, low maternal and fetal weights also increase the relative risk of schizophrenia (Wahlbeck et al. 2001). Malnutrition and obesity during pregnancy represent two extremes, but both are associated with marked hypercortisolemia (Langley-Evans et al. 1996; Lesage et al. 2001; Chalew et al. 1995; Raber 1998; Bjorntorp and Rosmond 2000; Livingstone et al. 2000). Thus, these seemingly contradictory data are still consistent with the putative hypothesis that stress hormones contribute to the elevated risk in these populations.

The hypothesis that hypercortisolemia during a critical period of gestation increases the risk of schizophrenia is parsimonious, as it unifies several studies into a single framework. It also has biological plausibility, for glucocorticoids have been shown to influence early brain development in laboratory animal studies. Alterations attributed to in utero stress or glucocorticoids have been found in brain anatomy, in the adult stress response, and in behavior. This evidence on the neurobiological effects of early glucocorticoid exposure warrants examination in some detail.

\section{SUPPORTIVE DATA}

\section{Effects of Cortisol on Early Brain Development: Changes in the Adult Stress Response}

Takahashi et al. (1992) and Henry et al. (1994) first reported that repeated restraint stress during gestation enhances the responsiveness of the offspring's hypothalamic-pituitary-adrenal (HPA) axis to acute stress during adulthood. These studies show that exposure to prenatal stress reprograms the HPA axis and leads to a diminished ability to inhibit stress-induced glucocorticoid secretion. This reprogramming is probably the consequence of selective and long-term decreases in type I and type II glucocorticoid receptors in the hippocampus (Henry et al. 1994; Koehl et al. 1999). Further experiments demonstrated that treatment of pregnant female rats with dexamethasone during the final week of gestation selectively decreases the expression of Type I and II glucocorticoid receptors in the hippocampus of the adult offspring (Welberg et al. 2001). The decrease in hippocampal receptors for glucocorticoids causes impaired negative feedback regulation of the HPA axis that is particularly prominent during times of stress. Post-mortem studies also revealed a decrease in glucocorticoid receptor expression in brain tissue obtained from schizophrenic patients (Knable et al. 2001). The increase in glucocorticoid secretion after stress present in adult prenatally-stressed experimental animals is associated with impaired cognitive capacity and diminished hippocampal volume (Lemaire et al. 2000). Cognitive impairments and smaller hippocampal volumes have also been observed in schizophrenic patients (Flaum et al. 1995; Bilder et al. 1995; Velakoulis et al. 1999; Stefanis et al. 1999; Gur et al. 2000; Kupferberg and Heckers, 2000; Walder et al. 2000). Patients with schizophrenia are also reported to have diminished feedback regulation of the HPA axis and other general abnormalities in HPA axis secretions (Yeragani 1990; Newcomer et al. 1991; Goldman et al. 1993; Lammers et al. 1995; Elman et al. 1998). Some investigations have failed to elucidate abnormal regulation of glucocorticoid secretion in schizophrenics (Jansen et al. 2000). However, strategies to reduce life stresses have been found to reduce the relapse rate for schizophrenic patients (Leff 1994). In a recent publication Walder et al. (2000) reported that the disruption in schizophrenic cognitive abilities are inversely correlated with the patient's HPA axis status. Additionally, these authors found symptom severity to be correlated with HPA status, making the relationship between schizophrenia 
and stress axis activity significantly stronger (Walder et al. 2000).

How can one be sure that glucocorticoids are involved in alterations in the developing brain? This question was addressed in a study by Barbazanges et al. (1996), which showed specifically that maternal adrenalectomy abolished the effects of prenatal restraint stress on the offspring. This study directly points to glucocorticoids as the agent responsible for reprogramming of the fetal central nervous system, in general and the stress axis, in particular. The dependence on glucocorticoids has been confirmed by treating pregnant dams with dexamethasone during the final week of gestation which also leads to reprogramming of the set point of the stress axis in the adult offspring (Welberg et al. 2001).

\section{Effects of Glucocorticoids on Early Brain Development: Neurochemical and Behavioral Changes}

Glucocorticoid hormones have been shown to augment dopaminergic neuronal function at many levels. These effects appear to be mediated by glucocorticoid receptors that are expressed in many dopamine (DA)-containing neurons in the brain (Harfstrand et al. 1986; Cintra et al. 1994). The presence of glucocorticoid hormones or stress during gestation also reprograms dopaminergic mechanisms in the brain. Glucocorticoids induce increases in DA metabolism (Tanganelli et al. 1990; Takahashi et al. 1992; Diaz et al. 1995; Barrot et al. 2000, 2001) in the striatum and increases in DA release in the nucleus accumbens (Piazza et al. 1996; Barrot et al. 2000), although decreased DA metabolism in the nucleus accumbens has also been reported (Alonso et al. 1994). With altered DA metabolism, changes in DA receptor function would be expected and increased D2 receptor binding has been reported in the nucleus accumbens (Henry et al. 1995). In human subjects, glucocorticoid administration also increases plasma HVA levels while inducing psychotic symptoms (Wolkowitz 1994). Furthermore, it has been shown that in order for stress to enhance the behavioral response to psychostimulants, glucocorticoids must be present (Deroche et al. 1992).

Studies have shown significant behavioral changes in animals exposed to glucocorticoids during the final week of gestation. While there is controversy about the exact effects of glucocorticoids and prenatal stress on DA neurochemistry, uniform results have been obtained in multiple labs demonstrating that prenatal stress or prenatal corticosterone administration increases amphetamine-induced locomotor behavior (Henry et al. 1995; Diaz et al. 1995; Koenig et al. 2001). In the case of prenatal stress, maternal glucocorticoids are responsible for the modulation of DA function ob- served in the adult offspring (Barbazanges et al. 1996). Increases in DA metabolism in schizophrenic patients were originally difficult to observe but using sophisticated imaging techniques in combination with an amphetamine challenge allowed investigators to demonstrate a heightened DA state in patients (Laruelle et al. 1996, 1999).

In addition to changes in DA neurotransmitter activity discussed above prenatal stress causes an increase in the turnover of norepinephrine in the cortex and locus coeruleus (Takahashi et al. 1992), and increases serotonin synthesis in fetal brain (Peters 1986, 1988, 1990), as well as concentrations of the brainstem serotonin transporter in rats (Slotkin et al. 1996). Alterations in serotonin-mediated behaviors develop between gestational days 15 and birth in rats (Peters 1988), a period that coincides closely with the first appearance of glucocorticoid receptors in the central nervous system on day 16 (Cintra et al. 1993). Therefore, early exposure to glucocorticoids also modifies the development of neurotransmitter systems proposed to be involved in the pathophysiology of schizophrenia, including norepinephrine, serotonin, dopamine and GABA (Davis et al. 1991; Roth and Meltzer 1995; Muneoka et al. 1997; Slotkin et al. 1996; Diaz et al. 1995, 1997; Lewis 2000).

Several additional pieces of behavioral evidence support the heuristic value of the prenatal stress model for schizophrenia:

First, Lemaire et al. (2000) reported that administration of repeated restraint stress during the final week of gestation causes a decrease in hippocampal neurogenesis in the offspring beginning as early as 28 days after birth. This decrease in cell birth persists throughout the life of the animal and causes a significant reduction in the number of granule cells present in the dentate gyrus of prenatally stressed animals. The reduction in the number of granule cells is associated with a diminished ability of the prenatally stressed rats to find a sunken platform in the Morris water maze demonstrating their reduced ability to remember spatial locations.

Second, we have found that the exposure of pregnant female rats to a chronic variable stress paradigm during the final week of gestation disrupted sensorimotor gating in the adult male offspring as reflected by deficits in prepulse inhibition. Pregnant rats stressed during the second week of gestation failed to demonstrate altered prepulse inhibition responses (Koenig et al. 2001). Isolation rearing, which appears to be a social stressor, also leads to abnormal prepulse inhibition (Varty and Geyer 1998). Cognitive deficits, disrupted hippocampal anatomy and deficits in sensorimotor gating, i.e. P50, are features commonly observed in schizophrenic patients (Flaum et al. 1995; Bilder et al. 1995; Freedman et al. 1997; Clementz et al. 1998; Velakoulis et al. 1999; Stefanis et al. 1999; Gur et al. 2000; Kupferberg and Heckers 2000; Walder et al. 2000). 
Third, in terms of brain development, the stage of human brain development in the second trimester of gestation is almost identical to rat brain development during days 14-21 of gestation (Bayer et al. 1993). These findings from animal experimentation enhance the likelihood that stress during gestation at an appropriate time may be a factor in the incidence of schizophrenia.

While neurotransmitter-related changes have been reported to arise as a result of prenatal exposure to glucocorticoids or stress, other brain factors involved in growth and differentiation of the brain may also be modified. For example, chronic treatment of adult rats with corticosterone reduces levels of the neural cell adhesion molecule (NCAM) in the hippocampus (Sandi and Loscertales 1999). Reduced NCAM levels have been noted in studies of post-mortem human schizophrenic brain tissue (Barbeau et al. 1995), and may account in part for the abnormal neuronal migration found in schizophrenia (Akbarian et al. 1996; Kirkpatrick et al. 1999), although there are also reports of increased expression of NCAM in schizophrenic brain tissue (Vawter et al. 1998). Interestingly, Wood et al. (1998) report that mice with decreased expression of NCAM show markedly enlarged ventricles and disrupted prepulse inhibition. These features also have been reported in schizophrenic patients. The expression of GAP-43, a cell recognition molecule, is similarly reduced in post-mortem schizophrenic human brain tissue (Eastwood and Harrison 1998), and the expression of GAP-43 is under the negative control of glucocorticoid hormones (Chao and McEwen 1994). Furthermore, prenatal exposure to glucocorticoids diminishes brain growth (Huang et al. 1999) while prenatal stress specifically decreases hippocampal volume (Lemaire et al. 2000); analogous changes have been reported in schizophrenic patients (Stefanis et al. 1999).

Lipska and Weinberger have developed a model for schizophrenia in rats using ibotenic acid lesions of the ventral hippocampus in seven-day-old rat pups. Damage to this structure induces hyperactivation of the dopamine (DA) system, behavioral changes that can be reversed by antipsychotic drugs (Lipska and Weinberger 1994) and sensory gating deficits (Lipska et al. 1995; Swerdlow et al. 1995). However, these lesions of the ventral hippocampus also lead to glucocorticoid hypersecretion (Herman et al. 1995). Considering that glucocorticoids are believed to enhance dopaminergic function (Casolini et al. 1993; Cho and Little 1999), the model proposed by Lipska and Weinberger may be attributable in part to the effect of hypersecreted glucocorticoids on the developing brain. Molteni et al. (2001) also report that the ventral hippocampal lesions produce modifications in the expression of brain-derived neurotrophic factor (BDNF) and fibroblast growth factor-2 (FGF-2) in the brains of these animals. The expression of both BDNF and FGF-2 is known to be modu- lated by glucocorticoid hormones (Smith et al. 1995; Riva et al. 1995). At present, however, the literature is vague about the direction of the change in BDNF expression in post-mortem human schizophrenic brain with both increased (Takahashi et al. 2000) and decreased (Weickert et al. 2001) expression being reported. BDNF is known to regulate $\gamma$-amino butyric acid (GABA) function (Rutherford et al. 1997) and DA D3 mechanisms providing an additional pathway through which glucocorticoids could act to modify neuronal growth, migration and survival.

\section{DISCUSSION}

The evidence that exposure to influenza in the second trimester of gestation increases the risk of schizophrenia in adult life is controversial. There are also important limitations to the reports of psychological stress during gestation as a risk factor for schizophrenia in adult life, as the number of studies is small, and the observed effect size in relation to schizophrenia is modest. In the case of some of the psychological stressors that have been cited, exact replications will not be possible because the exact circumstances cannot be reproduced. In addition, these stressors are often accompanied by other important factors that might be the true cause of any increase in risk (e.g., malnutrition and disease). In future studies of psychological stressors and risk of schizophrenia, clinical studies would benefit from careful attention to potentially confounding factors such as diet and infection.

The hypothesis that activation of the stress response during mid-gestation increases the risk of schizophrenia in the offspring provides a rational basis for the development of clinical, preclinical, and basic science research, and it merits further testing. This hypothesis has a strong biological plausibility, as analogous changes can be found in animals that have undergone prenatal stress, and the diverse stressors that have been studied to date lend themselves to a parsimonious mechanistic explanation.

Specific testable hypotheses that follow from this evidence include:

1. Prenatal stress in animals will lead to diminished hippocampal volume and impaired cognition, as measured by such tests as spatial delayed alternation, Morris water maze or novel object recognition recall paradigms. Impaired cognitive function is one of the major deficits in people with schizophrenia (Andreasen et al. 1999; Kupferberg and Heckers 2000).

2. In patients with schizophrenia, the response to stress may be augmented due to reduced glucocorticoid negative feedback. There is already some evidence 
consistent with this hypothesis (Kaneko et al. 1992; Tandon et al. 1991). Assessments of glucocorticoid receptor function in vivo, or mRNA and/or protein in post-mortem human brain tissue, could also be performed.

3. Animals exposed to prenatal stress will have anatomical alterations homologous to those found in postmortem studies of the brains of people with schizophrenia, such as decreased neuropil, changes in GABA cells, and increased density of the interstitial cells of the white matter (Selemon and GoldmanRakic 1999; Lewis et al. 1999; Lewis 2000; Akbarian et al. 1996; Kirkpatrick et al. 1999).

4. Animals exposed to prenatal stress will have changes in the serotonin (Breier 1995) and dopaminergic (Davis et al. 1991) systems similar to those found in the brains of people with schizophrenia, in addition to those already reported.

5. Animals exposed to prenatal stress will have behavioral abnormalities similar to those reported in animals with neonatal lesions of the dorsal hippocampus, and these abnormalities will be normalized with antipsychotic medications (Lipska and Weinberger 1994; Lillrank et al. 1995).

6. Treatment of women during at risk pregnancies with high doses of betamethasone to mature their potentially premature children's lungs is becoming increasingly accepted. It would be predicted that these children should show an increased incidence of schizophrenia in later life.

\section{CONCLUSION}

The hypothesis that exposure of the fetal brain to elevated glucocorticoids, resulting from the mother's stress response during gestation, increases the risk of schizophrenia is parsimonious, has biological plausibility, and it is consistent with several findings on the effects of prenatal stress in animals. Consideration of this hypothesis also focuses attention on the need for further studies of prenatal psychological stress, and the need for greater attention to be paid in such studies to potentially confounding variables such as infection, malnutrition, and physical injury. Schizophrenia research would benefit from a greater ability to use clinical and preclinical lines of research to illuminate each other, and to develop testable hypotheses in the other realm. This is now possible in the area of prenatal stress.

\section{ACKNOWLEDGMENTS}

This work was supported by grants from the Whitehall Foundation and DK52382 (JIK), a NARSAD Essel Distinguished Investigator award (BK), NIMH IRC grant and Novartis Pharma
AG. The authors wish to thank Dr. William T. Carpenter, Jr., and Dr. Robert Schwarcz for their editorial assistance with this manuscript.

\section{REFERENCES}

Akbarian S, Kim JJ, Potkin SG, Hetrick WP, Bunney WE Jr, Jones EG (1996): Maldistribution of interstitial neurons in prefrontal white matter of the brains of schizophrenic patients. Arch Gen Psychiatry 53:425-436

Alonso SJ, Navarro E, Rodriguez M (1994): Permanent dopaminergic alterations in the $n$. accumbens after prenatal stress. Pharmacol Biochem Behav 49:353-358

Andreasen NC, Nopoulous P, O'Leary DS, Miller DD, Wassink T, Flaum M (1999): Defining the phenotype of schizophrenia: cognitive dymetria and its neural mechanisms. Biol Psychiatry 46:908-920

Barbazanges A, Piazza PV, Le Moal M, Maccari S (1996): Maternal glucocorticoid secretion mediates long-term effects of prenatal stress. J Neurosci 16:3943-3949

Barbeau D, Liang JJ, Robitaille Y, Quirion R, Srivastava LK (1995): Decreased expression of the embryonic form of neural cell adhesion molecule in schizophrenic brains. Proc Natl Acad Sci USA 92:2785-2789

Barrot M, Abrous DN, Marinelli M, Rouge-Pont F, Le Moal M, Piazza PV (2001): Influence of glucocorticoids on dopaminergic transmission in the rat dorsolateral striatum. Eur J Neurosci 13:812-818

Barrot M, Marinelli M, Abrous DN, Rouge-Pont F, Le Moal M, Piazza PV (2000): The dopaminergic hyper-responsiveness of the shell of the nucleus accumbens is hormone-dependent. Eur J Neurosci 12:973-979

Bayer SA, Altman J, Russo RJ, Zhang X (1993): Timetables of neurogenesis in the human brain based on experimentally determined patterns in the rat. Neurotoxicology 14:83-144

Bilder RM, Bogerts B, Ashtari M, Wu H, Alvir JM, Jody D, Reiter G, Bell L, Lieberman JA (1995): Anterior hippocampal volume reductions predict frontal lobe dysfunction in first episode schizophrenia. Schizophr Res 17:47-58

Bjorntorp R, Rosmond R (2000): The metabolic syndrome-a neuroendocrine disorder? Br J Nutr 83(Suppl 1):S49-57

Breier A (1995): Serotonin, schizophrenia and antipsychotic drug action. Schizophr Res 14:187-202

Brixey SN, Gallagher BJ, McFalls JA, Parmelee LF (1993): Gestational and neonatal factors in the etiology of schizophrenia. J Clin Psychol 49:447-456

Brown AS, Schaefer CA, Wyatt RJ, Goetz R, Begg MD, Gorman JM, Susser ES (2000): Maternal exposure to respiratory infections and adult schizophrenia spectrum disorders: a prospective birth cohort study. Schizophr Bull 26:287-295

Casolini P, Kabbaj M, Leprat F, Piazza PV, Rouge-Pont F, Angelucci L, Simon H, Le Moal M, Maccari S (1993): Basal and stress-induced corticosterone secretion is decreased by lesion of mesencephalic dopaminergic neurons. Brain Res 622:311-314

Chalew S, Nagel H, Shore S (1995): The hypothalamic-pituitary-adrenal axis in obesity. Obes Res 3:371-382 
Chao HM, McEwen BS (1994): Glucocorticoids and the expression of mRNAs for neurotrophins, their receptors and GAP-43 in the rat hippocampus. Mol Brain Res $26: 271-276$

Cho K, Little HJ (1999): Effects of corticosterone on excitatory amino acid responses in dopamine-sensitive neurons in the ventral tegmental area. Neuroscience 88:837-845

Cintra A, Solfrini V, Bunnemann B, Okret S, Bortolotti F, Gustafsson JA, Fuxe K (1993): Prenatal development of glucocorticoid receptor gene expression and immunoreactivity in the rat brain and pituitary gland: A combined in situ hybridization and immunocytochemical analysis. Neuroendocrinology 57:1133-1147

Cintra A, Zoli M, Rosen L, Agnati LF, Okret S, Wikstrom AC, Gustafsson JA, Fuxe K (1994): Mapping and computer assisted morphometry and microdensitometry of glucocorticoid receptor immunoreactive neurons and glial cells in the rat central nervous system. Neuroscience 62:843-897

Clementz BA, Geyer MA, Braff DL (1998): Poor P50 suppression among schizophrenia patients and their first-degree biological relatives. Am J Psychiatry 155:1691-1694

Crow TJ (1987): Mutation and psychosis: A suggested explanation of seasonality of birth. Psychol Med 17:821-828

Crow TJ (1994): Prenatal exposure to influenza as a cause of schizophrenia. There are inconsistencies and contradictions in the evidence. Br J Psychiatry 164:588-592

Dalman C, Allebeck P, Cullberg J, Grunewald C, Koster M (1999): Obstetric complications and the risk of schizophrenia: A longitudinal study of a national birth cohort. Arch Gen Psychiatry 56:234-240

Davis KL, Kahn RS, Ko G, Davidson M (1991): Dopamine in schizophrenia: a review and reconceptualization. Am J Psychiatry 148:1474-1486

Deroche V, Piazza PV, Casolini P, Maccari S, Le Moal M, Simon $H$ (1992): Stress-induced sensitization to amphetamine and morphine psychomotor effects depend on stressinduced corticosterone secretion. Brain Res 598:343-348

Diaz R, Fuxe K, Ogren SO (1997): Prenatal corticosterone treatment induces long-term changes in spontaneous and apomorphine-mediated motor activity in male and female rats. Neuroscience 81:129-140

Diaz R, Ogren SO, Blum M, Fuxe K (1995): Prenatal corticosterone increases spontaneous and d-amphetamine induced locomotor activity and brain dopamine metabolism in prepubertal male and female rats. Neuroscience $66: 467-473$

Eastwood SL, Harrison PJ (1998): Hippocampal and cortical growth-associated protein-43 messenger RNA in schizophrenia. Neuroscience 86:437-448

Elman I, Adler CM, Malhotra AK, Bir C, Pickar D, Breier A (1998): Effect of acute metabolic stress on pituitaryadrenal axis activation in patients with schizophrenia. Am J Psychiatry 155:979-981

Falkenberg ER, Davis RO, DuBard M, Parker CR Jr (1999): Effects of maternal infections on fetal adrenal steroid production. Endocrine Res 25:239-249

Flaum M, O'Leary DS, Swayze VW 2nd, Miller DD, Arndt S, Andreasen NC (1995): Symptom dimensions and brain morphology in schizophrenia and related psychotic disorders. J Psychiatr Res 29:261-276
Freedman R, Coon H, Myles-Worsley M, Orr-Urtreger A, Olincy A, Davis A, Polymeropoulos M, Holik J, Hopkins J, Hoff M, Rosenthal J, Waldo MC, Reimherr F, Wendler P, Yaw J, Young DA, Breese CR, Adams C, Patterson D, Adler LE, Kruglyak L, Leonard S, Byerly W (1997): Linkage of a neurophysiological deficit in schizophrenia to a chromosome 15 locus. Proc Natl Acad Sci USA 94:587-592

Gardner DS, Fletcher AJW, Fowden AL, Giussani DA (2001): Plasma adrenocorticotropin and cortisol concentrations during acute hypoxemia after a reversible period of adverse intrauterine conditions in the ovine fetus during late gestation. Endocrinology 142:589-598

Goenjian AK, Yehuda R, Pynoos RS, Steinberg AM, Tashjian M, Yang RK, Najarian LM, Fairbanks LA (1996): Basal cortisol, dexamethasone suppression of cortisol, and MHPG in adolescents after the 1988 earthquake in Armenia. Am J Psychiatry 153:929-934

Goldman MB, Blake L, Marks RC, Hedeker D, Luchins DJ (1993): Association of nonsuppression of cortisol on the DST with primary polydipsia in chronic schizophrenia. Am J Psychiatry 150:653-655

Gur RE, Turetsky BI, Cowell PE, Finkelman C, Maany V, Grossman RI, Arnold SE, Bilker WB, Gur RC (2000): Temporolimbic volume reductions in schizophrenia. Arch Gen Psychiatry 57:769-775

Harfstrand A, Fuxe K, Cintra A, Agnati LF, Zini I, Wikstrom AC, Okret S, Yu ZY, Goldstein M, Steinbusch H, Gustafsson JA (1986): Glucocorticoid receptor immunoreactivity in monoaminergic neurons of rat brain. Proc Natl Acad Sci USA 83:9779-9783

Henry C, Kabbaj M, Simon H, Le Moal M, Maccari S (1994): Prenatal stress increases the hypothalamo-pituitaryadrenal axis response in young and adult rats. J Neuroendocrinol 6:341-345

Henry C, Guegant G, Cador M, Arnauld E, Arsaut J, Le Moal M, Demotes-Mainard J (1995): Prenatal stress in rats facilitates amphetamine-induced sensitization and induces long-lasting changes in dopamine receptors in the nucleus accumbens. Brain Res 685:179-186

Herman JP, Cullinan WE, Morano MI, Akil H, Watson SJ (1995): Contribution of the ventral subiculum to inhibitory regulation of the hypothalamo-pituitary-adrenocortical axis. J Neuroendocrinology 7:475-482

Huang WL, Beazley LD, Quinlivan JA, Evans SF, Newnham JP, Dunlop SA (1999): Effects of corticosteroids on brain growth in fetal sheep. Obstet Gynecol 94:213-218

Huttunen MO, Niskanen P (1978): Prenatal loss of father and psychiatric disorders. Arch Gen Psychiatry 35: 429-431

Imamura Y, Nakane Y, Ohta Y, Kondo H (1999): Life-time prevalence of schizophrenia among individuals prenatally exposed to atomic bomb radiation in Nagasaki. Acta Psychiatr Scand 100:344-349

Izumoto Y, Inoue S, Yasuda N (1999): Schizophrenia and the influenza epidemics of 1957 in Japan. Biol Psychiatry 46:119-124

Jansen LM, Gispen-de Wied CC, Kahn RS (2000): Selective impairments in the stress response in schizophrenic patients. Psychopharmacology 149:319-325

Jones PB, Ranatakallio P, Hartikainen AL, Isohanni M, Sipila 
P (1998): Schizophrenia as a long-term outcome of pregnancy, delivery and perinatal complications: a 28-year follow-up of the 1966 north Finland general population birth cohort. Am J Psychiatry 155:335-364.

Kaneko M, Yokoyama F, Hoshino Y, Takahagi K, Murata S, Wantanabe M, Kumashiro H, (1992): Hypothalamicpituitary-adrenal axis function in chronic schizaphrenia: Association with clinical features. Neuropsychobiology 25:1-7.

Kinney DK, Hyman W, Greetham C, Tramer S (1999): Increased relative risk for schizophrenia and prenatal exposure to a severe tornado. Schizophrenia Research 13:45-46.

Kirkpatrick B, Conley RC, Kakoyannis A, Reep RL, Roberts RC (1999): Interstitial cells of the white matter in the inferior parietal cortex in schizophrenia: An unbiased cell-counting study. Synapse 34:95-102.

Knable MB, Webster MJ, Bartko JJ, Torrey EF (2001): Multivariate analysis of prefrontal markers from the Stanley Foundation Neuropathology Consortium. Schizophrenia Res 49(Suppl):53

Koehl M, Darnaudery M, Dulluc J, Van Reeth O, Le Moal M, Maccari S (1999): Prenatal stress alters circadian activity of hypothalamo-pituitary-adrenal axis and hippocampal corticosteroid receptors in adult rats of both genders. J Neurobiol 40:302-315.

Koenig JI, Elmer GI, Brady D, Lee P, Minter J, (2001): In utero experience reprograms the central nervous system: A possible model for schizophrenia. Schizophrenia Res 49(suppl):92

Kunugi H, Nanko S, Takei N, Saito K, Hayashi N, Kazamatsuri H (1995): Schizophrenia following in utero exposure to the 1957 influenza epidemics in Japan. Am J Psychiatry 152:450-452

Kupferberg G, Heckers S (2000): Schizophrenia and cognitive function. Curr Opin Neurobiol 10:205-210

Lammers CH, Garcia-Borreguero D, Schmider J, Gotthardt U, Dettling M, Holsboer F, Heuser IJ (1995): Combined dexamethasone/corticotropin-releasing hormone test in patients with schizophrenia and in normal controls II. Biol Psychiatry 38:803-807

Lemaire V, Koehl M, Le Moal M, Abrous DN (2000): Prenatal stress produces learning deficits associated with an inhibition of neurogenesis in the hippocampus. Proc Natl Acad Sci USA 97:11032-11037

Langley-Evans SC, Gardner DS, Jackson AA, (1996): Maternal protein restriction influences the programming of the rat hypothalamic-pituitary-adrenal axis. J Nutr 126:1578-1585

Laruelle M, Abi-Dargham A, Gil R, Kegeles L, Innis R (1999): Increased dopamine transmission in schizophrenia: relationship to illness phases. Biol Psychiarty 46:56-72

Laruelle M, Abi-Dargham A, van Dyck CH, Gil R, D'Souza CD, Erdos J, McCance E, Rosenblatt W, Fingado C, Zoghbi SS, Baldwin RM, Seibyl JP, Krystal JH, Charney DS, Innis RB (1996): Single photon emission computerized tomography imaging of amphetamine-induced dopamine release in drug-free schizophrenia subjects. Proc Natl Acad Sci USA 93:9235-9240

Leff J (1994): Stress reduction in the social environment of schizophrenic patients. Acta Psychiatr Scand (Suppl 384):133-139

Lesage J, Blondeau B, Grino M, Breant B, Dupouy JP (2001): Maternal undernutrition during late gestation induces fetal overexposure to glucocorticoids and interuterine growth retardation, and disturbs the hypothalamo-pituitary adrenal axis in the newborn rat. Endocrinology 142:1692-1702

Lewis DA, Pierri JN, Volk DW, Melchitzky DS, Woo TU (1999): Altered GABA neurotransmission and prefrontal cortical dysfunction in schizophrenia. Biol Psychiatry 46:616-626

Lewis DA (2000): GABAergic local circuit neurons and prefrontal cortical dysfunction in schizophrenia. Brain Res Brain Res Rev 31:270-276

Lillrank SM, Lipska BK, Weinberger DR (1995): Neurodevelopmental animal models of schizophrenia. Clin Neurosci 3:98-104

Lipska BK, Weinberger DR (1994): Subchronic treatment with haloperidol and clozapine in rats with neonatal excitotoxic hippocampal damage. Neuropsychopharmacology 10:199-205

Lipska BK, Swerdlow NR, Geyer MA, Jaskiw GE, Braff DL, Weinberger DR (1995): Neonatal excitotoxic hippocampal damage in rats causes post-pubertal changes in prepulse inhibition of startle and its disruption by apomorphine. Psychopharmacology 122:35-43

Livingstone DE, Jones GC, Smith K, Jamieson PM, Andrew R, Kenyon CJ, Walker BR (2000): Understanding the role of glucocorticoids in obesity: Tissue-specific alterations in corticosterone metabolism in obese Zucker rats. Endocrinology 141:560-563

McGrath J, Castle D (1995): Does influenza cause schizophrenia? A five year review. Aust NZ J Psychiatry 29:23-31

Mednick SA, Huttunen MO, Machon RA (1994): Prenatal influenza infections and adult schizophrenia. Schizophr Bull 20:263-267

Mednick SA, Machon RA, Huttunen MO, Bonett D (1988): Adult schizophrenia following prenatal exposure to an influenza epidemic. Arch Gen Psychiatry 45:189-192

Molteni R, Lipska BK, Weinberger DK, Racagni G, Riva MA (2001): Developmental and stress-related changes of neurotrophic factor gene expression in an animal model of schizophrenia. Mol Psychiatry 6:285-292

Morgan V, Castle D, Page A, Fazio S, Gurrin L, Burton P, Montgomery P, Jablensky A (1997): Influenza epidemics and incidence of schizophrenia, affective disorders and mental retardation in Western Australia: No evidence of a major effect. Schizophr Res 26:25-39

Myhuman A; Rantakallio P; Isohanni M; Jones P; Partanen (1996): Unwantedness of a pregnancy and schizophrenia in the child. Br J Psychiatry 169:637-40

Muneoka K, Mikuni M, Ogawa T, Kitera K, Kamei K, Tukigawa M, Takahashi K (1997): Prental dexamethasone exposure alters brain monoamine metabolism and adrenocortical response in rat offspring. Am J Physiol 273:R1669-1675

Newcomer JW, Faustman WO, Whiteford HA, Moses JA Jr, Csernansky JG (1991): Symptomatology and cognitive impairment associate independently with post-dexam- 
ethasone cortisol concentrations in unmedicated schizophrenic patients. Biol Psychiatry 29:855-864

O'Callaghan E, Sham PC, Takei N, Murray G, Glover G, Hare EH, Murray RM (1994): The relationship of schizophrenic births to 16 infectious diseases. Br J Psychiatry 165:353-356

Parker CR Jr, Favor JK, Carden LG, Brown CH (1993): Effects of intrapartum stress on fetal adrenal function. Am J Obstet Gynecol 169:1407-1411

Peters DAV (1986): Prenatal stress increases the behavioral response to serotonin agonists and alters open field behavior in the rat. Pharmacol Biochem Behav 25:873-877

Peters DAV (1988): Effects of maternal stress during different gestational periods on the serotonergic system in adult rat offspring. Pharmacol Biochem Behav 31:839-843

Peters DAV (1990): Maternal stress increases fetal brain and neonatal cerebral cortex 5-hydroxytryptamine synthesis in rats: a possible mechanism by which stress influences brain development. Pharmacol Biochem Behav 35:943-947

Piazza PV, Rouge-Pont F, Deroche V, Maccari S, Simon H, Le Moal M (1996): Glucocorticoids have state-dependent stimulant effects on the mesencephalic dopaminergic transmission. Proc Natl Acad Sci USA 93:8716-8720

Plata-Salaman CR, Ilyin SE, Turrin NP, Gayle D, Flynn MC, Bedard T, Merali Z, Anisman H (2000): Neither acute nor chronic exposure to a naturalistic (predator) stressor influences the interleukin-1beta system, tumor necrosis factor-alpha, transforming growth factor-beta1, and neuropeptide mRNA in specific brain regions. Brain Res Bull 51:187-193

Raber J (1998): Detrimental effects of chronic hypothalamicpituitary-adrenal axis activation. From obesity to memory deficits. Mol Neurobiol 18:1-22

Riva MA, Fumagalli F, Blom JM, Donati E, Racagni G (1995): Adrenalectomy reduces FGF-1 and FGF-2 gene expression in specific rat brain regions and differentially affects their induction by seizures. Mol Brain Res 34:190-196

Rutherford LC, DeWan A, Lauer HM, Turrigiano GG (1997): Brain-derived neurotrophic factor mediates the activity dependent regulation of inhibition in neocortical cultures. J Neurosci 17:4527-4535

Roth BL, Meltzer HY (1995): The role of serotonin in schizophrenia. In Bloom FE, Kupfer DJ (eds), Psychopharmacology: The Fourth Generation of Progress. New York, Raven Press, pp 1215-1227

Sandi C, Loscertales M (1999): Opposite effects on NCAM expression in the rat frontal cortex induced by acute vs. chronic corticosterone treatments. Brain Res 828:127134

Schaefer CA, Brown AS, Wyatt RJ, Kline J, Begg MD, Bresnahan MA, Susser ES (2000): Maternal prepregnant body mass and risk of schizophrenia in adult offspring. Schizophr Bull 26:275-286

Selemon LD, Goldman-Rakic PS (1999): The reduced neuropil hypothesis: a circuit based model of schizophrenia. Biol Psychiatry 45:17-25

Selten JP, van der Graaf Y, van Duursen R, Gispen-de Wied CC, Kahn RS (1999): Psychotic illness after prenatal exposure to the 1953 Dutch Flood Disaster. Schizophr Res 35:243-245
Slotkin TA, Barnes GA, McCook EC, Seidler FS (1996): Programming of brainstem serotonin transporter development by prenatal glucocorticoids. Brain Res Dev Brain Res 93:155-161

Smith MA, Makino S, Kventnansky R, Post RM (1995): Stress and glucocorticoids affect the expression of brainderived neurotrophic factor and neurotrophin-3 mRNA in the hippocampus. J Neurosci 15:1768-1777

Smith RS (1992): A comprehensive macrophage-T-lymphocyte theory of schizophrenia. Med Hypotheses 39:248-257

Stefanis N, Frangou S, Yakeley J, Sharma T, O'Connell P, Morgan K, Sigmudsson T, Taylor M, Murray R (1999): Hippocampal volume reduction in schizophrenia: Effects of genetic risk and pregnancy and birth complications. Biol Psychiatry 46:697-702

Susser E, Lin SP, Brown AS, Lumey LH, Erlenmeyer-Kimling L (1994): No relation between risk of schizophrenia and prenatal exposure to influenza in Holland. Am J Psychiatry 151:922-924

Susser E, Neugebauer R, Hoek HW, Brown AS, Lin S, Labovitz D, Gorman JM (1996): Schizophrenia after prenatal famine. Further evidence. Arch Gen Psychiatry 53:25-31

Suvisaari J, Haukka J, Tanskanen A, Hovi T, Lonnqvist J (1999): Association between prenatal exposure to poliovirus infection and adult schizophrenia. Am J Psychiatry 156:1100-1102

Swerdlow NR, Lipska BK, Weinberger DR, Braff DL, Jaskiw GE, Geyer MA (1995): Increased sensitivity to the sensorimotor gating-disruptive effects of apomorphine after lesions of medial prefrontal cortex or ventral hippocampus in adult rats. Psychopharmacology 122:27-34

Takahashi LK, Turner JG, Kalin NH (1992): Prenatal stress alters brain catecholaminergic activity and potentiates stressinduced behavior in adult rats. Brain Res 574: 131-137

Takahashi M, Shirakawa O, Toyooka K, Kitamura N, Hashimoto T, Maeda K, Koizumi S, Wakabayashi K, Takahashi H, Someya T, Nawa H (2000): Abnormal expression of brain-derived neurotrophic factor and its receptor in the corticolimbic system of schizophrenic patients. Mol Psychiatry 5:293-300

Takaki A, Huang QH, Somogyvari-Vigh A, Arimura A (1994): Immobilization stress may increase plasma interleukin-6 via central and peripheral catecholamines. Neuroimmunomodulation 1:335-342

Tandon R, Mazzara C, DeQuardo J, Craig KA, Meador-Woodruff JH, Goldman R, Greden JF (1991): Dexamethasone suppression test in schizophrenia: Relationship to symptomatology, ventricular enlargement and outcome. Biol Psychiatry 15:953-964

Tanganelli S, Fuxe K, von Euler G, Eneroth P, Agnati LF, Ungerstedt $U$ (1990): Changes in pituitary-adrenal activity affect the apomorphine-and cholecystokinin-8induced changes in striatal dopamine release using microdialysis. J Neural Transm Gen Sect 81:183-194

Torrey EF, Miller J, Rawlings R, Yolken RH (1997): Seasonality of births in schizophrenia and bipolar disorder: a review of the literature. Schizophr Res 28:1-38

Torrey EF, Rawlings R, Waldman IN (1988): Schizophrenic births and viral diseases in two states. Schizophr Res 1:73-77

Trgovcich J, Ryman K, Extrom P, Elderidge JC, Aronson JF, 
Johnston RE (1997): Sindbis virus infection of neonatal mice results in a severe stress response. Virology 227:234-238

Turnbull AV, Rivier CL (1999): Regulation of the hypothalamic-pituitary-adrenal axis by cytokines: actions and mechanisms of action. Physiol Rev 79:1-71

van Os J, Selten JP (1998): Prenatal exposure to maternal stress and subsequent schizophrenia. The May 1940 invasion of The Netherlands. Br J Psychiatry 172:324326

Varty GB, Geyer MA (1998): Effects of isolation rearing on startle reactivity, habituation, and prepulse inhibition in male Lewis, Sprague-Dawley and Fischer F344 rats. Behav Neuroscience 112:1-8

Vawter MP, Cannon-Spoor HE, Hemperly JJ, Hyde TM, VanderPutten DM, Kleinman JE, Freed WJ (1998): Abnormal expression of cell recognition molecules in schizophrenia. Exp Neurol 149:424-432

Velakoulis D, Pantelis C, McGorry PD, Dudgeon P, Brewer W, Cook M, Desmond P, Bridle N, Tierney P, Murrie V, Singh B, Copolov D (1999): Hippocampal volume in first-episode psychoses and chronic schizophrenia: A high resolution magnetic resonance imaging study. Arch Gen Psychiatry 56:133-141

Wahlbeck K, Forsen T, Osmond C, Barker DJP, Eriksson JG (2001): Association of schizophrenia with low maternal body mass index, small size at birth, and thiness during childhood. Arch Gen Psychiatry 58:48-52

Walder DJ, Walker EF, Lewine RJ (2000): Cognitive function- ing, cortisol release, and symptom severity in patients with schizophrenia. Biol Psychiatry 48:1121-1132

Weickert CS, Hyde TM, Eisenberg N, Romanczyk, JE Kleinman (2001); Expression of full-length trkB mRNA in hippocampus of patients with schizophrenia. Schizophrenia Bull 49(Suppl):57

Welberg LAM, Seckl JR, Holmes MC (2001): Prenatal glucocorticoid programming of brain corticosteroid receptors and corticotrophin-releasing hormone: Possible implications for behavior. Neuroscience 104:71-79

Wood GK, Tomasiewicz H, Rutishauser U, Magnuson T, Quirion R, Rochford J, Srivastava LK (1998): NCAM-180 knockout mice display increased lateral ventricle size and reduced prepulse inhibition of startle. Neuroreport 9:461-466

Wolkowitz OM (1994): Prospective controlled studies of the behavior and biological effects of exogenous corticosteroids. Psychoneuroendocrinology 19:233-255

Westergaard T, Mortensen PB, Pedersen CB, Wohlfahrt J, Melbye M (1999): Exposure to prenatal and childhood infections and the risk of schizophrenia: suggestions from a study of sibship characteristics and influenza prevalence. Arch Gen Psychiatry 56:993-998

Wright P, Gill M, Murray RM (1993): Schizophrenia: genetics and the maternal immune response to viral infection. Am J Med Genet 48:40-46

Yeragani VK (1990): The incidence of abnormal dexamethasone suppression in schizophrenia: a review and a meta-analysis comparison with the incidence in normal controls. Can J Psychiatry 35:128-132 